\title{
Relationship of Mineralogy and Paleoenvironments in the Late Pleistocene Kalimati to Sunakothi and Thimi Formations, Kathmandu Basin, Central, Nepal
}

\author{
Mukunda Raj Paudel \\ Department of Geology, Trichandra Campus \\ Tribhuvan University, Ghantaghar, Kathmandu, Nepal \\ Email:mukunda67@gmail.com
}

\begin{abstract}
The investigation was carried out on mineralogical composition of the three different stratigraphic units of the Kathmandu Basin-fill sediments. On the basis of the variation of the non-clay and clay fraction, here the investigation was interpreted to establish the paleoenvironmental and paleoclimatic condition during the deposition from the lacustrine facies of the Kalimati Formation to the fluvio-lacustrine facies of the Sunakothi Formation and probable caused of these change. Both Kalimati and Sunakothi sediments contain same mineral composition while Thimi sediments did not contain carbonate (calcite) minerals and amount of mica is higher than the Sunakothi and Kalimati sediments. Higher amount of smectite within the clay fraction and presence of calcite within both clay and non-clay fraction in the basal part of the Sunakothi Formation indicates seasonal and prolong dry climatic condition occurred during the deposition of the Kalimati Formation to Sunakothi Formation. On the other hand, lower amount of kaolinite/smectite ratio, and excess amount of carbonate mineral within the basal part of the Sunakothi Formation shows depositional environmental changes from deep to shallow, and lake water became more alkaline. Gradually lacustrine condition changes into the fluvio-lacustrine condition. On the other hand, higher ratio of the kaolinite/smectite within the Kalimati Formation to lower ratio of the kaolinite/smectite within the basal part of the Sunakothi Formation indicates that climatic condition was more seasonal and cold/ dry than the Kalimati Formation. Both kaolinite/smectite and smectite/illite value indicate paleoprecipitation of the Kathmandu valley, was higher during the Kalimati phase than the Sunakothi.
\end{abstract}

Key words: Kathmandu Basin, Kalimati, Sunakothi and Thimi sediments, calcite, smectite

\section{INTRODUCTION}

Thick sandy and muddy sequence located above the lacustrine facies of the Kalimati Formation toward the North and South of the Kathmandu Valley is Thimi and Sunakothi Formation (Fm) proposed by Paudel and Sakai 2006. These two formations are bounded near the Hanumante and Manohara Kholas at the central part of the basin, and have many hidden histories about the late Pleistocene climatic change and its linkage to the draining of the ancient lake water and became fertile valley for human settlement. Yoshida and Igarashi (1984), Sakai (2001), Sakai et al. (2001), and Dill et al. (2001) studied the sedimentological and stratigraphic research works of the Thimi Fm, and proposed the fluviodeltaic facies deposited during the younger stage of the Paleo-Kathmandu Lake. Paudel and Sakai (2004 \& 2006) proposed fluvio-lacustrine facies covered the lacustrine facies of the Kalimati Formation towards the south of the Kathmandu Basin. Both two formations are composed by coarse to fine sediments, hence mineralogical study especially both clay and non-clay minerals can provide important records about the paleoclimatic and paleoenvironmental interpretation of these two formations, and their significances for the process and causes of the draining of the ancient lake water from the paleo-Kathmandu lake during the late Pleistocene to early Holocene periods. Kuwahara et al. (2001), Fujii et al. (2001) reported mineralogical variation and its significance for the paleoclimatic interpretation of the open lacustrine stage of the paleo-Kathmandu lake at the central part of the Kathmandu Basin. However, systematic mineralogical study encompasses of all stratigraphic units aren't performed still yet.

In order to reconstruct the paleoenvironmental changes during the deposition of the Kalimati to Sunakothi and Thimi Formations, the total amount of minerals and their variation within the three formations are estimated. similarly, crstallinity of the illite, chlorite, smectite and amount of variation of the illite, kaolinite and smectite can provide the climatic condition of the Kathmandu Valley 
during the deposition of these sediments. The objective of this paper is to reconstruct the paleoenvironment changes from Kalimati to Sulakothi \& Thimi Formations on the basis of non-clay $\&$ clay minerals variations.

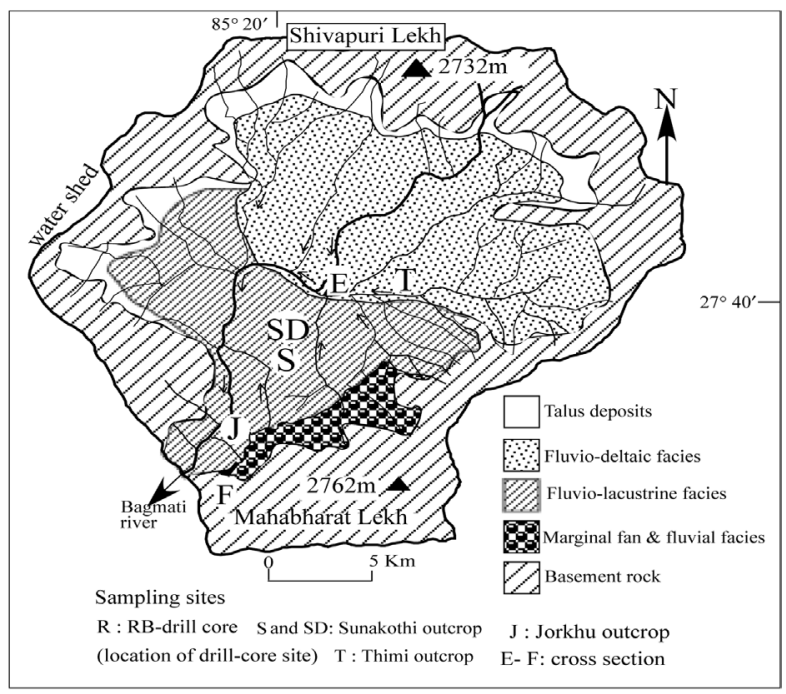

Fig.1. Facies map of the Kathmandu Basin showing the sampling sites of the outcrop of the Sunakothi Formation (J, SD \& S), out crop of the Thimi Formation (T).

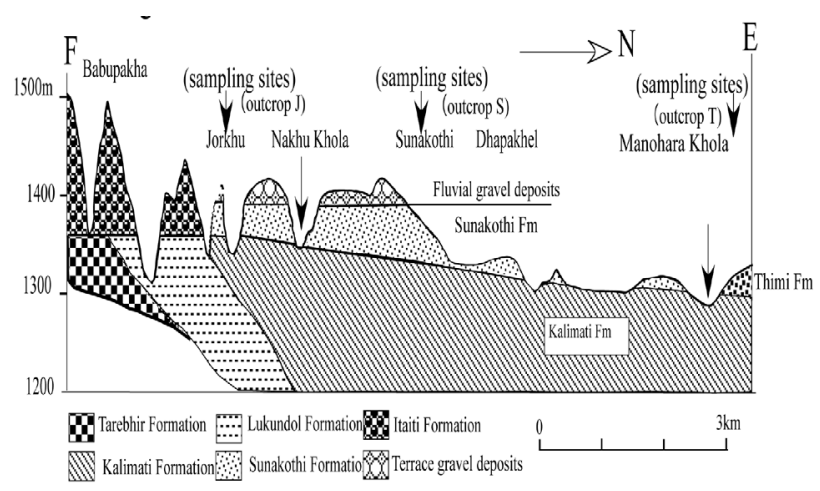

Fig. 2. Simplified geological cross-section (E-F) across the Kathmandu Basin showing different stratigraphic units with sampling sites for mineralogical study.

\section{MATERIALS AND METHODS}

Total 94 samples of the outcrop of the Sunakothi, Thimi and Kalimati Formations (Fm) of the Kathmandu Basin, and 10 representative present river sediments for clay fraction studied were collected for the XRD experiments (Figs $1 \& 2$ ). The sample was dried for 24 hours at $50^{\circ} \mathrm{C}$ in air bath and then weighed. The dry sample was divided into two fractions, clay (less than $2 \mu \mathrm{m}$ ) and non-clay part (greater than $2 \mu \mathrm{m}$ ) by the gravity sedimentation methods. Non-clay part of the samples was dried for 24 hours at $50^{\circ} \mathrm{C}$ on the hot plate and then weighed. This sample was then made powder in the agate mortar. Finally, 10 wt. \% of zincite $(\mathrm{ZnO})$ was added as an internal standard into this powder samples. Zincite is suitable for the internal standard for XRD quantitative analysis because it provides stronger and more conveniently located reflection (Srodon et al 2001). Each clay fraction of the sample was collected by the Millipore ${ }^{\circledR}$ filter $(0.45$ $\mu \mathrm{m}$ pore, $47 \mathrm{~mm}$ diameter) transfer method to provide an optimal orientation (Moore and Reynolds 1989). Both air-dried (AD) and ethylene glycol solvated (EG) preparations were done for each sample.

XRD measurement were done by the Rigaku X-ray Diffractometer RINT $2100 \mathrm{~V}$, using $\mathrm{CuK} \square$ radiation monochromatized by a curve graphite crystal in a step of $0.02^{\circ}$ with a step-counting time of 2 second. The profile-fitting obtained XRD pattern was performed with an Apple Power Macintosh computer and a scientific graphical analysis program XRD MacDiff (Petschik, 2000). The result of the individual mineral obtained from the profile-fitting method was used for quantitative analysis.

Relative amounts of minerals of the different stratigraphic units in the Kathmandu Basin were determined by calibration curve obtained from integrated intensity ratio of the standard mineral to internal standard zincite.

Mixture of $10 \mathrm{wt} \%$ internal standard zincite and a known percentage of each standard mineral was analyzed by XRD under the same condition describe above. The integrated intensity of each mineral was estimated from XRD data using a program XRD MacDiff (Petschik, 2000).

\section{RESULTS}

\section{XRD results of the non-clay fraction}

Samples collected from three different locations within the Sunakothi Fm (J, S \& SD; Fig.1) from the southern to the central part of the basin and one location at the Thimi Fm at Thimi outcrop ( $\mathrm{T}$ at Fig.1 and 2). Main component minerals of the sediments are quartz, K-feldspar, plagioclase, mica, calcite, and chlorite. All three locations of the Sunakothi Fm show higher amount of these minerals ranging from 100 to $44 \mathrm{wt} \%$ (Table 1). Constituents of these minerals are quartz (86-6 wt\%), K-feldspar (20-1 wt.\%), plagioclase (9-1wt\%), mica (14$1 \mathrm{wt} \%$ ), chlorite (14-0wt\%), and calcite (46-1wt\%) (Fig. 3). All three locations show relatively higher amount of K-feldspar than the plagioclase feldspar (Figs. 5a to $5 \mathrm{c})$. Amount of mica, chlorite and calcite is higher in the southern outcrops than the north of the Sunakothi 


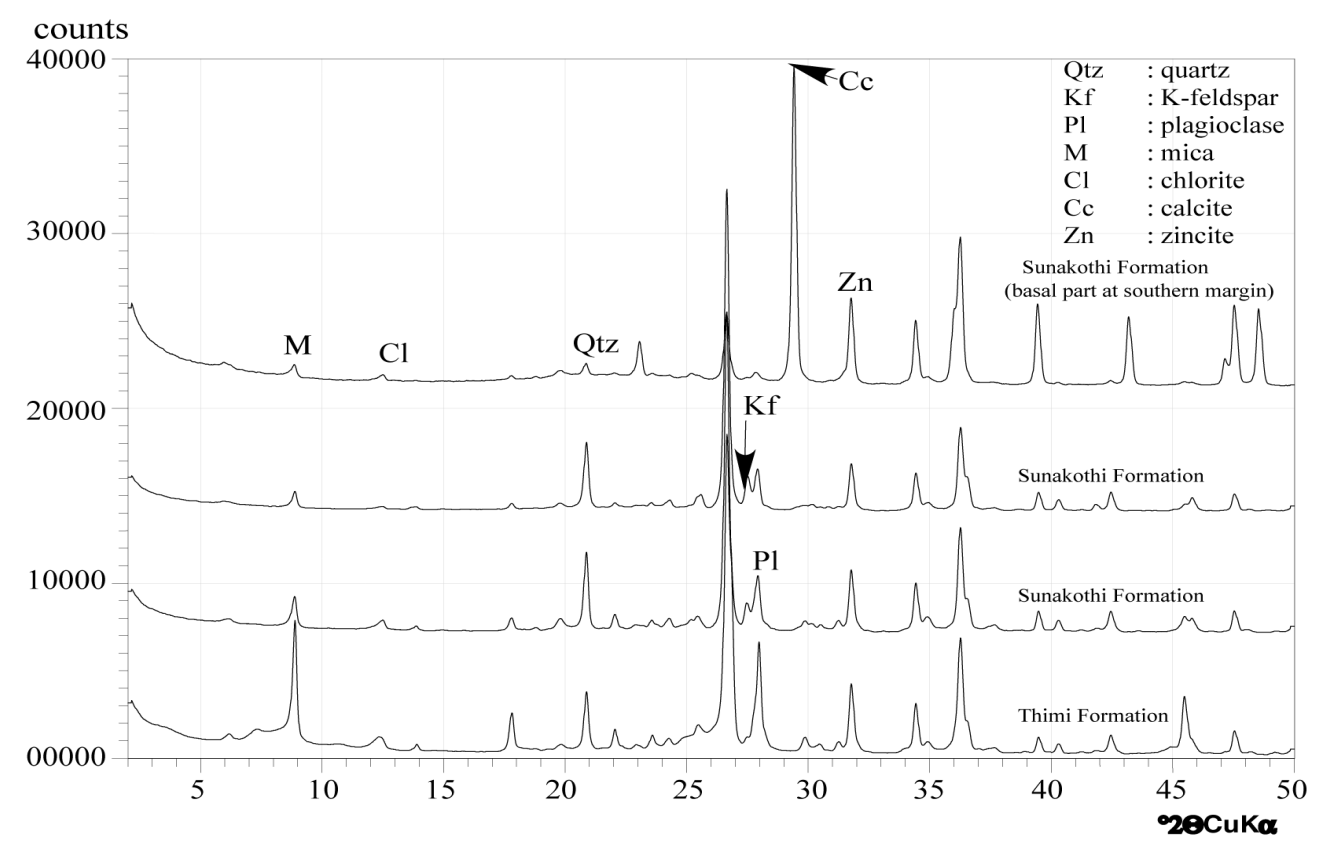

Fig.3: XRD patterns of the non-clay fraction of the Thimi, Sunakothi and Kalimati sediments showing main components minerals.

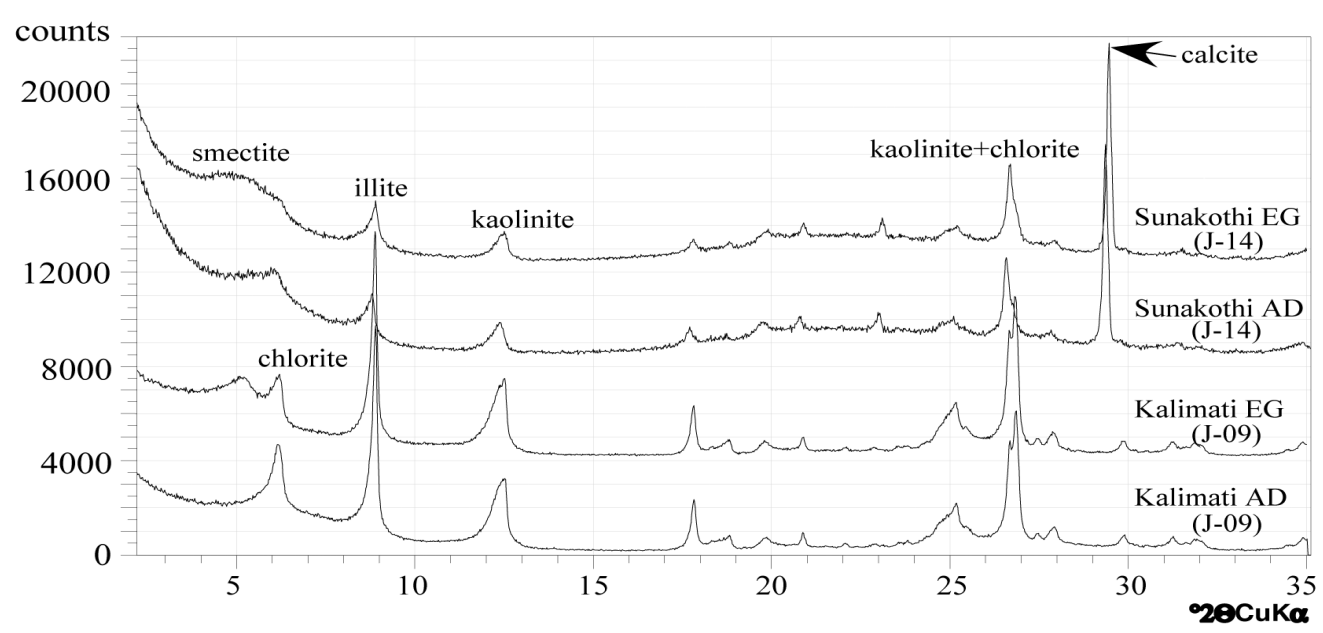

Fig.4: XRD patterns of the clay fraction of the Sunakothi and Kalimati sediments showing main clay minerals.

Fm (Table 1A to 1B, \& Figs. 5a-5c). Except the basal part of the Sunakothi Fm, among the non-clay fraction sediments of all three locations, quartz and feldspar is more than $65 \mathrm{wt} \%$. Basal part contains higher amount of calcite reaching maximum 46wt \% (Table 1A). Except calcite one location of the Thimi Fm shows same components of the minerals as Sunakothi Fm (Table 1B, Fig. 6). However, the amount of each mineral within this formation is different from Kalimati to Sunakothi Fm (Fig.6).

At the basin margin outcrop ( $\mathrm{J}$ at location Fig.2) lacustrine facies of the Kalimati Fm shows same mineral composition as the Sunakothi sediments. However amount of the calcite is only very low to terrace amount (less than $0.5 \mathrm{wt} \%$ ). Similar result obtained from the lower to upper part of the Sunakothi Fm. The XRD result of the Thimi sediments, where amount of quartz is relatively low, and mica is relatively higher than the Sunakothi sediments (Fig. 5a-5c \& 6). The amount of plagioclase within the Sunakothi sediments is lower than the Thimi sediments. 
Table 1. The amount of non-clay mineral (wt \%) and their average value within (1A) Kalimati to Sunakothi Formation at basin margin outcrop J at Fig.1 (1B) Thimi to Sunakothi Formation at S and T at Fig.1.

\begin{tabular}{|c|c|c|c|c|c|c|c|c|}
\hline & Parts & amount & quartz & K-feldspar & plagioclase & mica & chlorite & calcite \\
\hline & & maximum & 80 & 18 & 4 & 14 & 14 & 5 \\
\hline & lower to upper & average & 52 & 7 & 2 & 9 & 9 & 2 \\
\hline \multirow[t]{5}{*}{ Sunakothi Fm } & & minimum & 18 & 1 & 1 & 3 & 3 & 1 \\
\hline & & maximum & 50 & 20 & 4 & 11 & 5 & 46 \\
\hline & basal part & average & 28 & 8 & 3 & 8 & 3 & 17 \\
\hline & & minimum & 6 & 1 & 1 & 3 & 1 & 1 \\
\hline & & maximum & 50 & 20 & 6 & 15 & 15 & 8 \\
\hline \multicolumn{2}{|c|}{ Kalimati Fm } & average & 41 & 9 & 4 & 10 & 9 & 3 \\
\hline & & minimum & 34 & 1 & 1 & 9 & 6 & 1 \\
\hline
\end{tabular}

\begin{tabular}{|c|c|c|c|c|c|c|c|}
\hline \multicolumn{8}{|l|}{ Table.1(B): } \\
\hline \multirow[t]{2}{*}{ Formation } & Parts & amount & quartz & K-feldspar & plagioclase & mica & chlorite \\
\hline & & maximum & 86 & 21 & 9 & 9 & 3 \\
\hline \multirow[t]{3}{*}{ Sunakothi Fm } & lower to upper & average & 59 & 11 & 4 & 6 & 1 \\
\hline & & minimum & 21 & 4 & 2 & 3 & 0 \\
\hline & & maximum & 75 & 25 & 11 & 32 & 12 \\
\hline \multicolumn{2}{|c|}{ Thimi Fm } & average & 49 & 12 & 6 & 17 & 3 \\
\hline & & minimum & 33 & 5 & 1 & 8 & 0 \\
\hline
\end{tabular}

Table 2. Amount of clay minerals within the Sunakothi and Kalimati sediments and their crystallinity value

\begin{tabular}{|c|c|c|c|c|c|c|c|c|}
\hline units & sample no. & $\% \mathrm{sm}$ & \% kao & $\%$ illi & $\%$ chlo & IC & $\mathrm{CC}$ & SC \\
\hline & $\mathrm{J}-10$ & 4 & 10 & 67 & 19 & 0.2 & 0.5 & 1.38 \\
\hline & $\mathrm{J}-9$ & 6 & 11 & 66 & 17 & 0.2 & 0.3 & 1.41 \\
\hline & $\mathrm{J}-8$ & 1 & 8 & 63 & 28 & 0.2 & 0.6 & 1.07 \\
\hline & $\mathrm{J}-7$ & 5 & 11 & 70 & 14 & 0.2 & 0.3 & 1.37 \\
\hline \multirow[t]{7}{*}{ Kalimati Fm } & J-6 & 5 & 9 & 68 & 18 & 0.3 & 0.8 & 1.36 \\
\hline & $\mathrm{J}-4$ & 10 & 11 & 62 & 18 & 0.2 & 0.4 & 1.41 \\
\hline & $\mathrm{J}-3$ & 8 & 10 & 63 & 20 & 0.2 & 0.4 & 1.1 \\
\hline & $\mathrm{J}-2$ & 4 & 10 & 69 & 18 & 0.3 & 0.3 & 1.04 \\
\hline & $\mathrm{J}-11$ & 6 & 13 & 62 & 19 & 0.3 & 0.5 & 1.4 \\
\hline & $\mathrm{J}-12$ & 12 & 8 & 65 & 15 & 0.3 & 0.6 & 1.56 \\
\hline & $\mathrm{J}-13$ & 15 & 8 & 59 & 18 & 0.3 & 0.7 & 1.47 \\
\hline Sunakothi Fm & $\mathrm{J}-14$ & 16 & 12 & 56 & 16 & 0.3 & 0.6 & 1.44 \\
\hline \multirow[t]{5}{*}{ (basal part) } & $J-15$ & 17 & 10 & 57 & 15 & 0.3 & 0.8 & 1.53 \\
\hline & $\mathrm{J}-16$ & 10 & 6 & 63 & 21 & 0.3 & 0.6 & 1.43 \\
\hline & $\mathrm{J}-17$ & 6 & 8 & 70 & 16 & 0.2 & 0.5 & 1.5 \\
\hline & $\mathrm{J}-18$ & 10 & 12 & 57 & 22 & 0.2 & 0.5 & 1.5 \\
\hline & $\mathrm{J}-19$ & 10 & 10 & 56 & 25 & 0.2 & 0.6 & 1.47 \\
\hline Sunakothi Fm & $\mathrm{J}-21$ & 8 & 9 & 54 & 29 & 0.2 & 0.4 & 1.46 \\
\hline (lower to upper & $\mathrm{J}-26$ & 5 & 11 & 63 & 21 & 0.2 & 0.4 & 1.34 \\
\hline part) & $\mathrm{J}-31$ & 12 & 11 & 61 & 16 & 0.2 & 0.4 & 1.63 \\
\hline
\end{tabular}


Relationship of Mineralogy and Paleoenvironments in the Late Pleistocene Kalimati to Sunakothi and Thimi Formations ....

Table 3. Amount of clay minerals within the present river sediments (PR) and their crystallinity value.

\begin{tabular}{|c|c|c|c|c|c|c|c|c|c|}
\hline area & locality & clay wt. $\%$ & smectite & I/C (R=1) & illite & chlorite & kaolinite & IC & CI \\
\hline north & 4 & 3.3 & - & ++ & +++ & + & ++ & 0.42 & 0.41 \\
\hline north & 5 & 0.3 & + & ++ & +++ & + & ++ & 0.44 & 0.37 \\
\hline north & 6 & 4.8 & - & ++ & +++ & + & ++ & 0.51 & 0.46 \\
\hline north & 7 & 0.1 & - & ++ & +++ & + & ++ & 0.4 & 0.38 \\
\hline north & 9 & 3.2 & - & ++ & +++ & + & ++ & 0.46 & 0.43 \\
\hline west & 26 & 0.5 & - & ++ & +++ & ++ & + & 0.31 & 0.46 \\
\hline west & 27 & 0.4 & + & ++ & +++ & + & + & 0.48 & 1.94 \\
\hline east & 15 & 5 & - & ++ & +++ & + & ++ & 0.3 & 0.52 \\
\hline south & 24 & 1.7 & + & + & +++ & + & + & 0.23 & 0.36 \\
\hline south & 23 & 1.9 & - & + & +++ & + & + & 0.27 & 0.35 \\
\hline
\end{tabular}

Relative amounts of each clay minerals: - : trace amount, + : low, ++ : medium, +++ : high

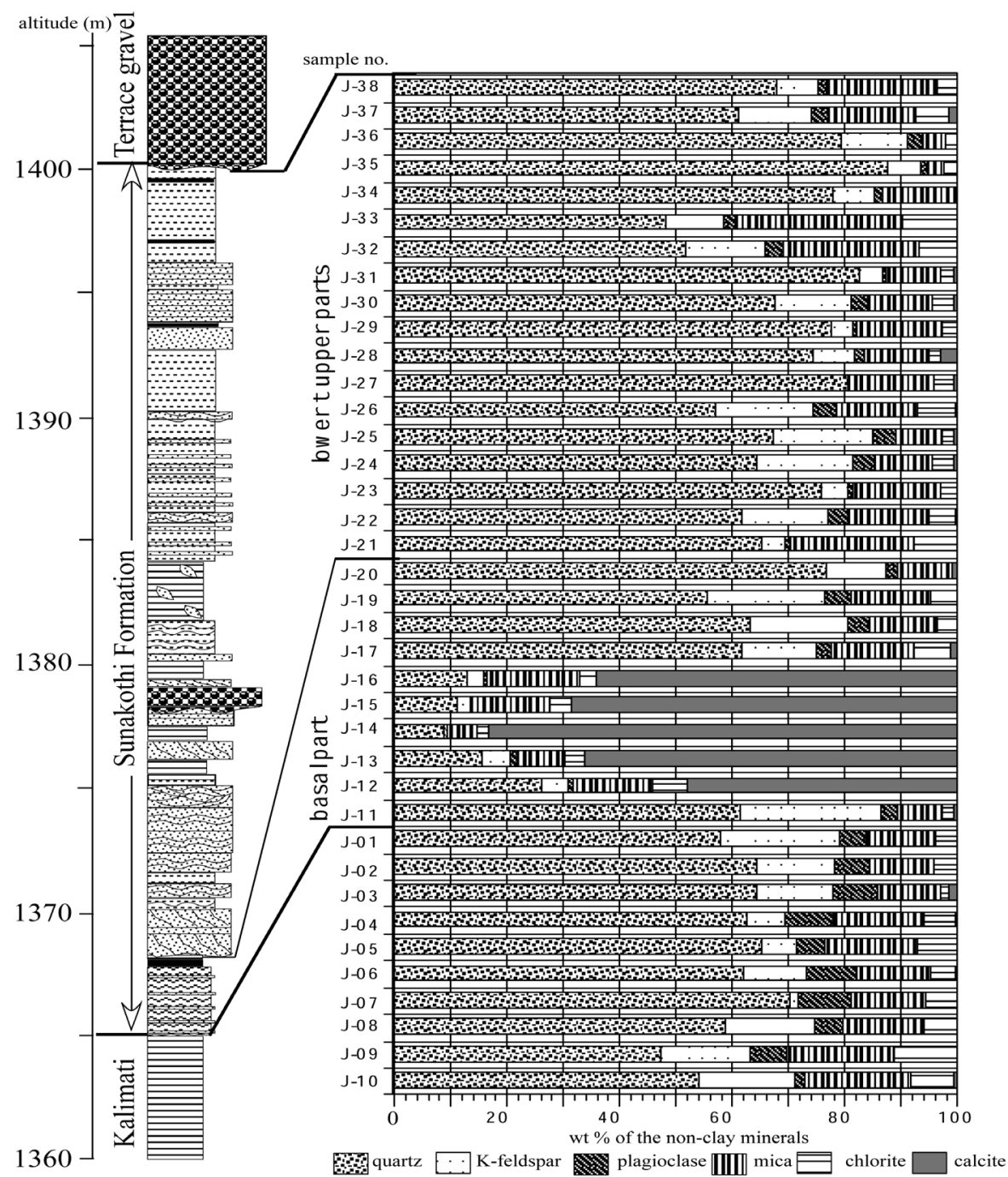

(a) 


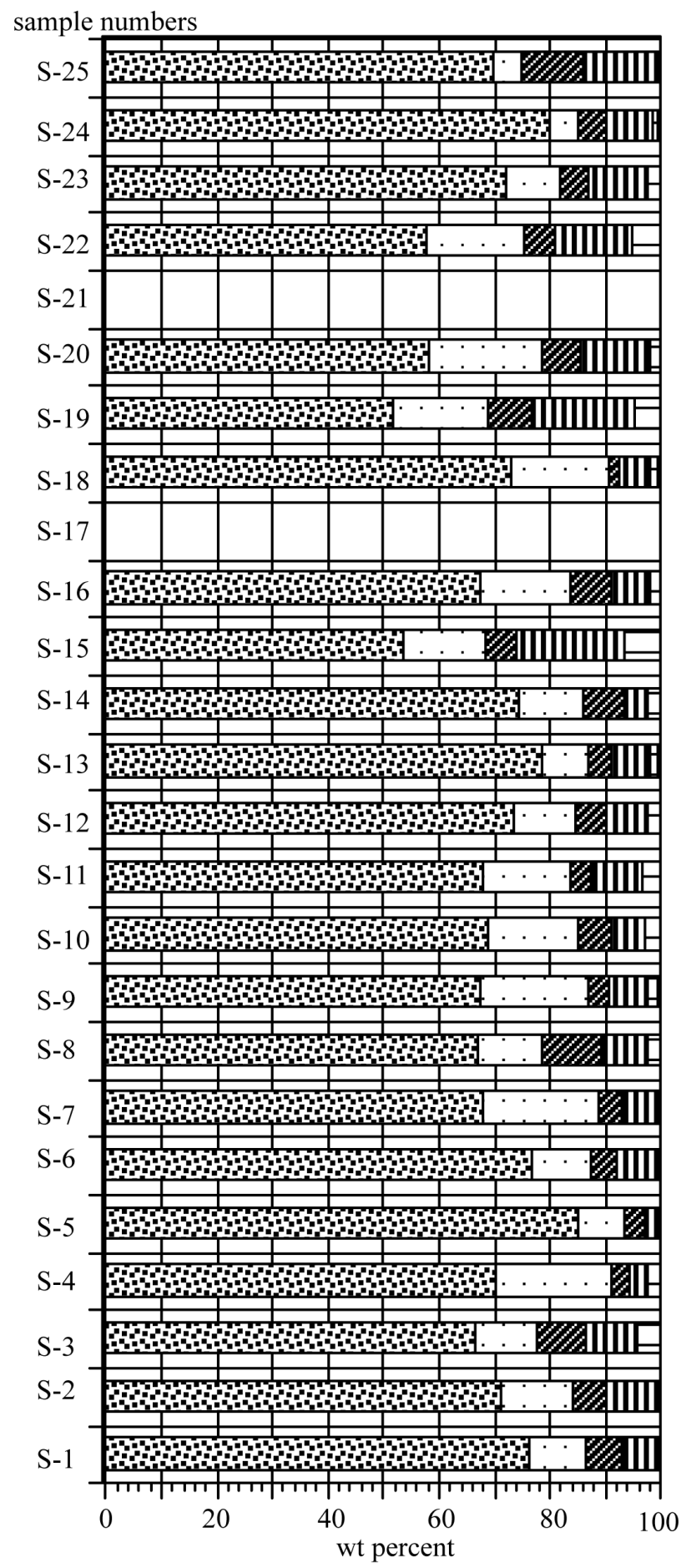

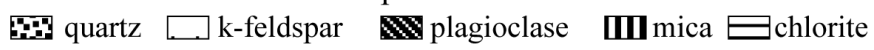

(b) sample numbers

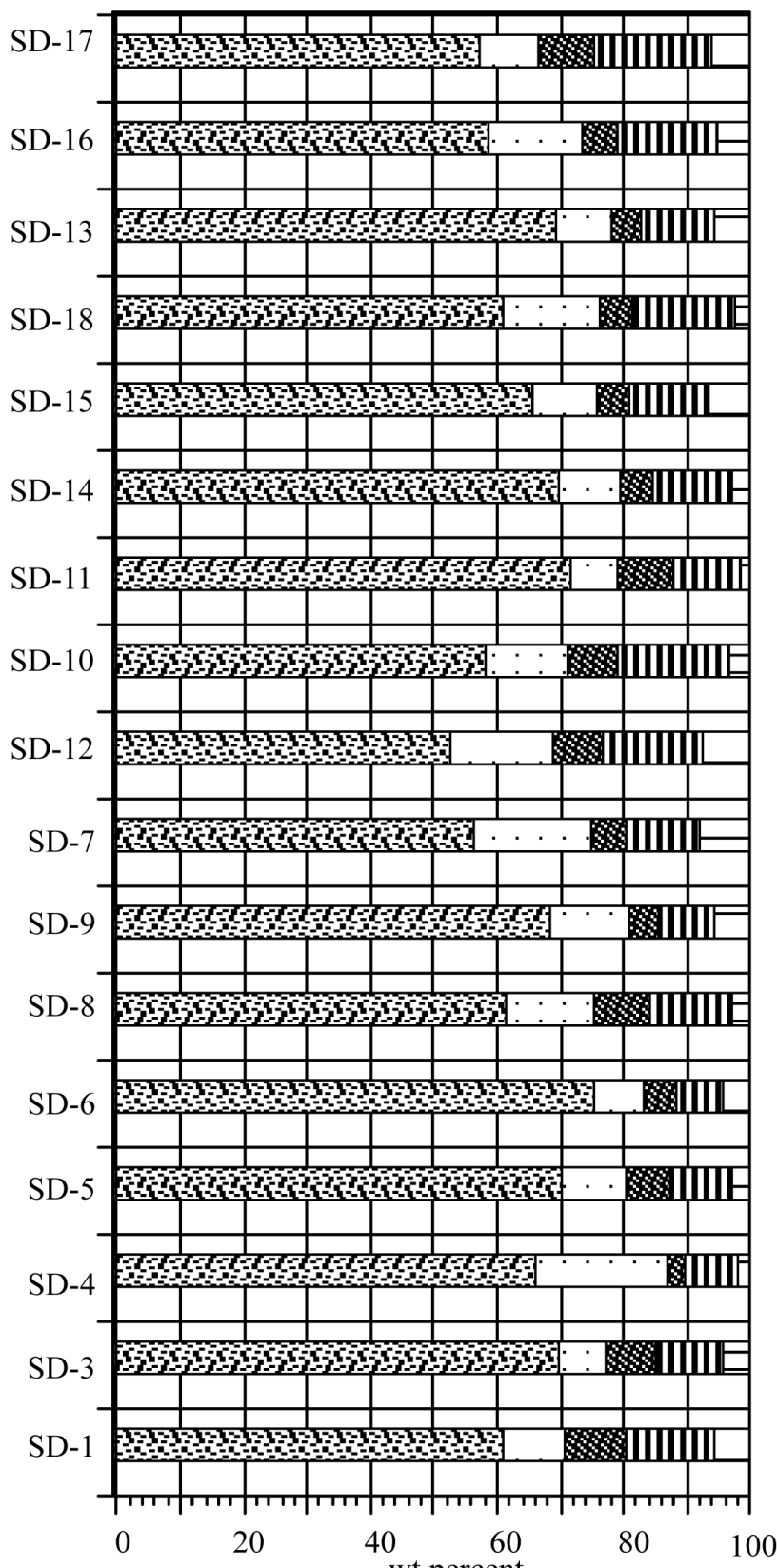

Fig. 5. Amount of non-clay mineral of the Sunakothi sediments: (5a) at the basin margin out crop, J at Fig.1 (5b) at the center $S$ at Fig. 1, (5c) SD at the Fig. 1. 


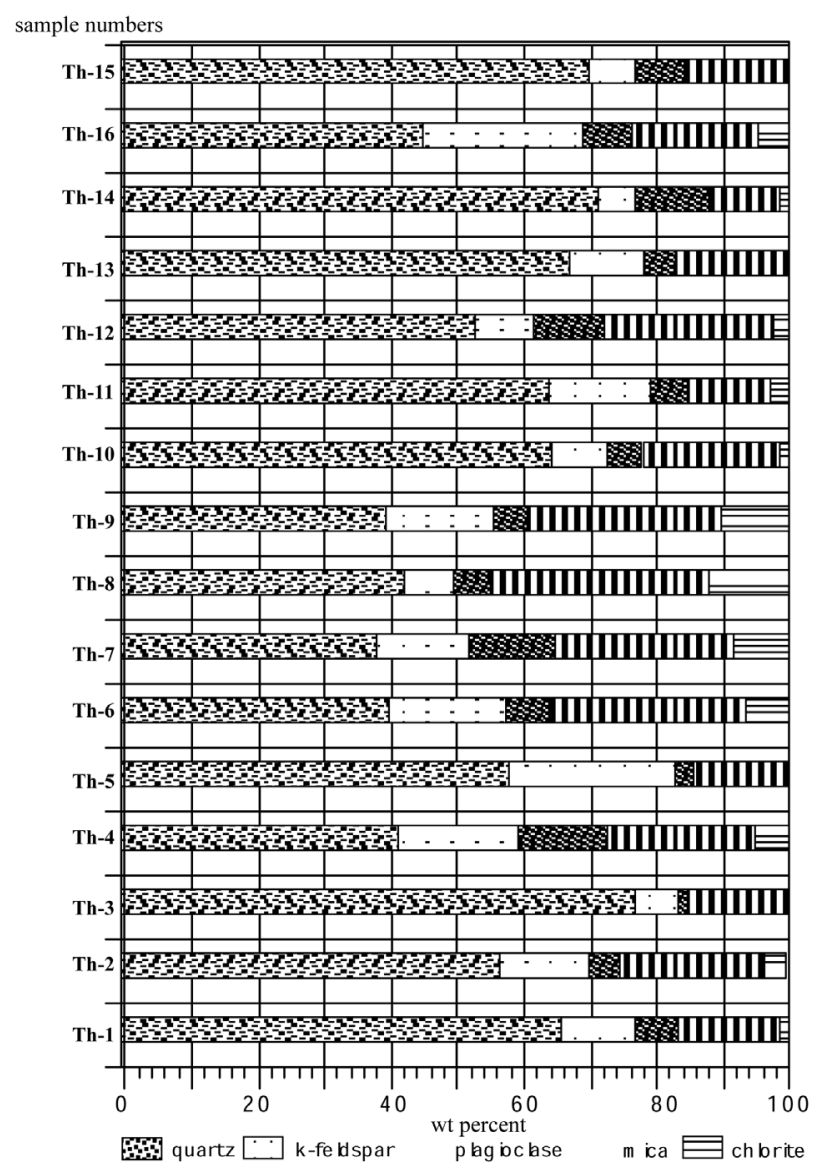

Fig.6. Amount of non-clay mineral of the Thimi sediments, $T$ at Fig.1

XRD results of the clay fraction within the Kalimati and Sunakothi sediments

XRD result of the clay fraction within the Sunakothi formation (Fig. 4) is shown in the Table. 2 and Fig. 7. The clay mineral assemblages in the Sunakothi formation in the southern part of the basin include illite, chlorite, smectite, kaolinite and some amount of mixed layer minerals. Among these minerals illite is the dominant clay fraction within the sediments. The amount of the kaolinite is not different from Kalimati to the Sunakothi Formation, while chlorite also shows the same amount from Kalimati to Sunakothi Formation while lower to upper part of the Sunakothi formation shows higher amount than the Kalimati formation and basal part of the Sunakothi formation. Both amount of illite and smectite differ from Kalimati to Sunakothi formation. Kalimati sediments shows higher amount of illite than the basal part of the Sunakothi formation, while other parts show same amount as Kalimati sediments. Higher amount of smectite is detected within the basal part and lower to upper part of the Sunakothi formation. The amount of smectite shows nearly twice than the Kalimati sediments (Table.2).

Illite crystallinity index (IC), chlorite crystallinity index (CI) and smectite crystallinity (SC) show low amount within the all samples except the basal part of the Sunakothi Formation (Table 2 and Fig.7). Except some horizon of the basal part of the Sunakothi SC index didn't exceed 1.5 . All other horizon shows nearly 1.5 . SC index is low within the sediments of the Kalimati formation than the lower to upper part of the Sunakothi formation. IC value did not exceed 0.4 in all samples (Table 2). Overall trend of these three indexes shows slightly higher value within the Sunakothi sediments. Both kaolinite/ smectite, and smectite/illite shows amount of smectite is high within the basal part than the Kalimati formation and lower to upper part of the Sunakothi formation.

\section{Amount of clay fraction, IC and CI value of the present river sediments}

Ten representative samples of the present river sediments of the clay size fraction show the illite is the dominant minerals within the sediments which is more than 80 $\mathrm{wt} \%$, and chlorite, mixed layer $\mathrm{I} / \mathrm{S}, \mathrm{I} / \mathrm{C}$ are the other minerals. Smectite is only in the trace amount within the sediments (Table. 3). The illite crystallinity index (IC), and chlorite crystallinity index (CI) are nearly 0.4 and 0.5 to 0.7 (Table 3).

\section{DISCUSSIONS}

Variation of the non-clay and clay minerals within the Kalimati, Thimi and Sunakothi Formations

XRD analysis of the greater than $2 \mu \mathrm{m}$ fraction indicates. following trend of the mineral variation occurred within the three formations: quartz is higher amount within the Sunakothi formation than the Thimi and Kalimati formations, while K-feldspar is more or less equal within the Thimi formation and lower to upper part of the Sunakothi formation. Plagioclase is higher amount within the Thimi than the Kalimati and Sunakothi formations. The amount of mica is nearly twice within the Thimi formation than the Sunakothi formation, while amount of the mica is high within the Kalimati formation than the Sunakothi formation (Table 1A \& 1B). Amount of chlorite is nearly equal within the lower to upper part of the Sunakothi and Kalimati formations. Maximum amount of calcite was detected at the basal part of the Sunakothi formation ranging from 1 to $46 \mathrm{wt} \%$. Other parts of this formation contains very few to trace amount of calcite minerals. Thimi sediements did not contain 


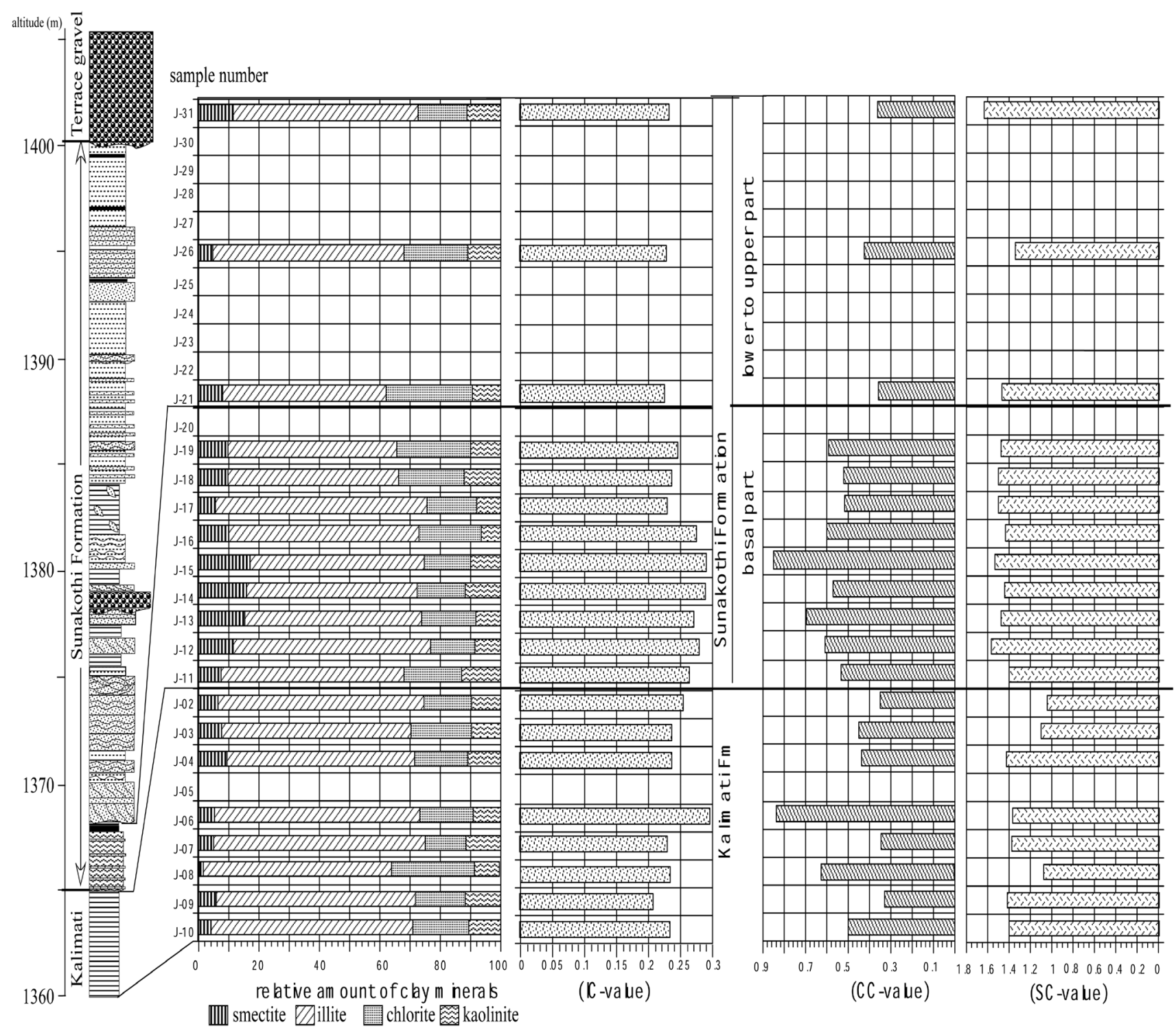

Fig. 7. The amount of clay fraction minerals within the Sunakothi and Kalimati sediments at the basin margin outcrop (J at Fig. 1). IC, CI and SC represent the illite crystallinity, chlorite crystallinity and smectite crystallinity value of each clay minerals at the same location.

calcite while the amount of calcite within the Kalimati formation is lower than the basal part of the Sunakothi formation and higher than the lower to upper part of the Sunakothi formation.

Southern outcrop near the basin margin (J, at Fig. 1) contains higher amount of calcite than the basin center within (S \& SD, at Fig. 1) the Sunakothi formation. South, East and West of the Kathmandu Valley contain carbonate rocks. However, maximum amount of calcite was only detected within the basal part of the Sunakothi formation. It is most probably due to the dissolution of the calcite minerals with in the water of the river when $\mathrm{pH}$ condition was favorable for the dissolution. In the basal part of the Sunakothi formation amount of calcite is higher than the silicate minerals. Chlorite is detected from all samples of the Sunakothi formation, which is also detected in the Kalimati and Thimi formations. The amount of chlorite shows higher at the Kalimati and basal part of the Sunakothi formations, while the lower to upper part of the Sunakothi formation shows very low amount of this minerals. The amount of mica and feldspar is higher amount within the basin margin than the basin center of the Sunakothi formation. 
Among the clay minerals illite is higher in the Kalimati formation, while in the Sunakothi formation shows relatively lower amount than the Kalimati formation. Higher amount of illite is due to the weathering of the mica. The amount of smectite is two times higher than Sunakothi sediments (Fig. 7) in the basal part and slightly less than double in the lower to upper part of the Sunakothi formation than the Kalimati formation. Kaolinite did not show any different result within the Kalimati and Sunakothi formations while chlorite shows the same trend as the illite. K/S (kaolinite/smectite) ratio shows slightly higher value within the Kalimati and lower to upper part of the Sunakothi formations than the basal part of the Sunakothi formations (Table 2).

PR (present river sediments) sediments show that illite is the dominant mineral. In comparision to the IC and CI value between PR sediments and Sunakothi formation, IC value is greater than Sunakothi formation, while CI value is relatively lower than the Sunakothi formation (Table $1 \& 3$ ).

\section{Paleoenvironmental and paleoclimatic condition from Kalimati formation to Sunakothi formation}

Here, variation of non-clay and clay fraction as the key mineral was used for the depositional environmental changes of the Kathmandu Basin-fill sediments. The amount of clay fraction is high in wet climatic condition in the lacustrine environment of the Kathmandu Basin. As the amount of precipitation increased, it forced to raise the flow of water; the alteration of the primary rock-forming minerals like plagioclase, as well as the deposition of the clay and weathering of these clay minerals itself is high. Moreover, at the time of lowering of the lake the suspension deposition is less pronounce than the bed load deposition so clay did not reach the basin center. In addition, higher amount of non-clay especially feldspar and quartz may indicate dry period and dominant of the fluvial depositional environment and inflow of the river water within the lake, low amount indicates humid period. When climatic condition became dry in the lake environment, water level in the lake went down and dissolved calcareous matter were precipitated in the lake bottom. The precipitation of calcite minerals indicates that the $\mathrm{pH}$ of the lake water at the time of deposition was very alkaline condition. Hence, in this time period total amount of silicate minerals was decreased due to the dissolution of the silicate and precipitation of the calcite minerals.

On the other hand, crystalinity of the chlorite, illite and smectite is depending on the weathering condition of the depositional basin. In the cold climate chemical weathering is weak due to low precipitation rate and low temperature. In such a climatic condition above three minerals show good crystallinity index (i.e. low value of $\mathrm{IC}, \mathrm{CC}$ and SC), while condition is reversed during the wet period due to higher rate of weathering ( Chamley 1989, Robert 2004, Thamban et al. 2002). On the other hand, higher amount of smectite shows seasonal and more drier climatic condition. In this period lake became alkaline and favorable for the precipitation of the carbonate (calcite) within the lake basin.

Considering the above facts higher amount of smectite and calcite at the basal part of the Sunakothi formation indicates that the climatic condition was more seasonal, cold and dry, which are favorable for the formation of the alkaline condition. Conversely, sediments of the Kalimati formation in the southern part of the basin shows higher amount of K/S ratio than the Sunakothi formation. On the other hand, amount of mica is high within this formation than the Sunakothi Formation. It indicates that climatic condition was changed from more wet to dry during the deposition from Kalimati formation to Sunakothi formation. On the basis of IC value among the PR sedimens, Sunakothi and Kalimati formations, Sunakothi formation was deposited during the colder period than the present climatic condition of the Kathmandu Valley indicated by the lower amount of IC within the Sunakothi formation than the PR sediments. On the other hand, Kalimati formation deposited more wet and humid indicated by the higher value of the IC of the Kalimati formation than the PR and Sunakothi formation.

In comparison of the mineralogical variation among Kalimati, Sunakothi and Thimi sediments with geology of the Kathmandu Valley, it seems that the provenance of the sediments is not just from one particular direction. Even though the samples were insufficient for studying the whole Kathmandu Basin-fill sediments, it is possible to interpret northern origin of the Thimi Fm, and southern origin of the Sunakothi Fm indicated by the higher amount of mica from the north and quartz from metasediments zone of the Kathmandu Valley. Northern origin is indicated by mica and chlorite rich with quartz poor. On the other hand, east, west and south source contains higher amount of quartz than the northern source with mica and chlorite poor.

\section{CONCLUSIONS}

The mineralogical studies of the clay and non-clay fraction within the three stratigraphic units (Kalimati, Sunakothi and Thimi) show both climatic and depositional 
environmental changes occurred during the deposition of these sediments. Higher amount of kaolinite/smectite ratio, and excess amount of carbonate mineral within the basal part of the Sunakothi Fm shows depositional environmental changes from deep to shallow, and lake water became more alkaline. Gradually lacustrine condition changes into the fluvio-lacustrine condition (lakedelta which is represented by Sunakothi formation). On the other hand, higher ratio of the kaolinite/smectite within the Kalimati Fm to lower ratio of the kaolinite/ smectite within the basal part of the Sunakothi sediments indicates climatic condition of more seasonal and dry than that of the Kalimati formation.

\section{ACKNOWLEDGEMENTS}

This research is my one part of research in Kyushu University, Japan. I express my thanks to Prof. Harutaka Sakai, all member of PKL Project and all faculty members of Department of Social and cultural studies Kyushu University, Japan. I would like to express my thank to Dr. Hiroshi Nisi Hokkaido University, Dr. Y. Kuwahara, Dr. Masao Ohno and Dr. Kiyotaki Ishida, Kyushu University for various cooperation. I extend my sincere gratitude to Prof. B. N. Upreti, and all members of the Department of Geology, Tribhuvaan University Nepal for their support and suggestions. I extend acknowledge to the Director General and staff of the Department of mines and Geology Nepal for necessary help and cooperation to bring the samples to Kyushu University. I also acknowledge to the Dr. Satoshi Funakawa (Former JOCV Volunteer in Tribhuvan University, Nepal)

\section{REFERENCES}

Chamley, H. 1989. Clay Mineralogy. Springer, Berlin, 623 p.

Dill, H. G., Khadka, D.R., Khanal, R., Dohrmann, R., Melcher, F. and Busch, K. 2003. Infilling of the Younger Kathmandu-Banepa intermontane lake basin during the Late Quaternary (Lesser Himalaya, Nepal): a sedimentological study. Jour. Quat. Sci. 18: 41-60.

Fujii, R., Kuwahara, Y. and Sakai, H. 2001. Mineral composition changes recorded in the sediments from a 284-m-long drill-well in central part of the Kathmandu Basin, Nepal. Jour. Nepal Geol. Soc. 25 (Sp.Issue): 63-70.

Kuwahara,Y., Fujii, R., Masudome, Y. and Sakai, H. 2001. Measurement of Crystallinity and relative amount of clay mineral in the Kathmandu Basin sediments by decomposition of XRD pattern (profile fitting). Jour. Nepal Geol. Soc.25 (Sp.Issue):71-80.

Kuwahara,Y., Paudel, M.R., Makai, T., Fujii, R. and
Sakai, H. 2004. Variation of the paleoclimate and paleoenvironment during the last 40ka recorded in clay minerals in the Kathmandu Basin sediments. Hima. Jour. Sci. 2 (issue 4):190-191.

Petschick, R. 2000. Mac DiffVer.4.2.3, Manual. GeologischPalaontologisches Institute Johann Wolfgang Goethe Universitat Frankfurt am Main Senckenberganlage 32-34,60054 Frankfurt am Main, Germany, 58 p.

Paudel, M. R., Kuwahara, Y., and Sakai, H. 2004. Changes in mineral composition and depositional environments recorded in the present and past basin-fill sediments of the Kathmandu Valley, central Nepal. Himalayan Jour. Sciences 2: 222-223.

Paudel, M. R and Sakai, H. 2004. Stratigraphy and depositional environment of the basin-fill sediments in the southern part of the Kathmandu Valley, central Nepal, Abstract, the 111 Annual meeting of the, Geological Society of Japan: 308

Paudel, M. R. and Sakai, H. 2006. Late Pleistocene depositional environmental changes in the draining stage of the Paleo-Kathmandu Lake in the southern part of the Kathmandu Basin, Central Nepal, ISC Fukuoka 2006: 177

Rai, S. M. 2001. Geology, geochemistry, and radiochronology of the Kathmandu and Gosainkund Crystalline nappe, central Nepal Himalaya. Nepal. Jour., Nepal Geol., Soc. 25 (Sp issue): 135-155.

Robert, C. 2004. Late Quatenary variability of precipitation in Southern Callifornia and climatic implication: clay mineral evidence from the Santa Barbara Basin. ODP Site 893, Quatenary Science reviews: 10291040.

Sakai,T., Gajurel, A. P., Tabata, H., and Upreti, B. N. 2001. Small amplitude lake level fluctuations recorded in aggrading delta deposits of the upper Pleistocene Thimi and Gokarna formation, Kathmandu Valley. Nepal. Jour. Nepal Geol. Soc. 25(Sp. Issue): 43-51.

Sakai, H., Fujii R. and Kuwahara, Y. 2002. Change in the depositional system of the Paleo-Kathmandu Lake caused by uplift of the Nepal Lesser Himalayas. Jour. Asian Earth Sci.20: 267-276.

Stocklin, J. and Bhattari, K. D. 1981. Geological map of the Kathmandu area and central Mahabharat Range, Nepal Himalayas. HMG Nepal/UNDP report. 64p.

Thamban, M., Purnachandra, R., Schneider, R.R., 2002. Reconstruction of the late Quaternary monsoon oscillation based on clay mineral proxies using sediment cores from the western margin of India. Marine Geology 186: 527-539.

Yoshida, M and Igarashi, Y. 1984. Neogene to Quaternary laustrine sediments in the Kathmandu Valley, Nepal. Jour. Nepal Geol., Soc., 4 (Sp Issue): 73-100. 